\title{
PURIFICATION AND CHARACTERIZATION OF THE NEWLY THERMOSTABLE PROTEASE PRODUCED BY Brevibacillus thermoruber LII ISOLATED FROM PADANG CERMIN HOTSPRING, INDONESIA
}

\section{Pemurnian dan Karakterisasi Protease Tahan Panas Baru yang Dihasilkan oleh Brevibacillus thermoruber LIl yang Diisolasi dari Sumber Air Panas Padang Cermin, Lampung, Indonesia}

\author{
Dewi Seswita Zilda ${ }^{1,2 *}$, Eni Harmayani' ${ }^{2)}$, Jaka Widada ${ }^{2)}$, Widya Asmara ${ }^{2)}$, Hari Eko Irianto ${ }^{1)}$, \\ Gintung Patantis ${ }^{1)}$, and Yusro Nuri Fawzya ${ }^{1)}$ \\ 1) Research and Development Center for Marine and Fishery Product Processing and Biotechnology, \\ JI. K.S. Tubun Petamburan VI, Jakarta Pusat, Indonesia 10260 \\ 2) Biotechnology Study Program, Gadjah Mada University, Yogyakarta, Indonesia \\ ${ }^{*}$ Correspondence Author: seswitazilda@yahoo.com \\ Article history: \\ Received: 10 January 2014; Revised: 18 April 2014; Accepted: 5 Mei 2014
}

\begin{abstract}
Thermostability is among of the vital enzyme characteristics for industrial application. Brevibacillus thermoruber LII was obtained as a potential isolate from the previous research which screened the potential thermostable protease producing bacteria from Indonesian hotspring. The newly thermostable protease produced by thermophilic Brevibacillus thermoruber LII had been purified and characterized. It was predicted that the pure enzyme obtained from Brevibacillus thermoruber LII was homo hexameric, having molecular weight of $36 \mathrm{kDa}$ unit protein and its native was $215 \mathrm{kDa}$. In addition, it was also a neutral metalo serine protease according to biochemical tests that it was totaly inhibited by PMSF (Phenylmethanesulfonyl fluoride) and EDTA (Ethylenediaminetetraacetic acid). It showed optimum activity at $\mathrm{pH}$ of 8 and active in acidic buffer (up to $\mathrm{pH}$ of 4 ). All of metal ion in the form of chloride salt $(2.5 \mathrm{mM})$ which were tested on the enzyme enhanced the enzyme activity but $\mathrm{Li}^{2+}$. $\mathrm{Ca}^{2+}$ ion increased the activity and the stability of enzyme against thermal. The enzyme also showed the stability against solvent. The protease LII had optimum temperature at $60^{\circ} \mathrm{C}$ without $\mathrm{CaCl}_{2}$ and $80-85^{\circ} \mathrm{C}$ with addition of $2.5 \mathrm{mM} \mathrm{CaCl}$. The $\mathrm{K}_{\mathrm{M}}$ and $\mathrm{V}_{\max }$ values for the purified protease LII were $27.2 \mathrm{mg} / \mathrm{ml}$ or $0.362-0.272 \mathrm{M}$ for substrate HammersteinCasein (MM 75-100 kDa) and $261.1 \mu \mathrm{g} / \mathrm{minute} / \mathrm{ml}$, respectively.
\end{abstract}

Keywords: thermostable protease, Brevibacillus thermoruber, hotspring

\begin{abstract}
ABSTRAK
Ketahanan terhadap panas merupakan salah satu sifat enzim yang penting untuk aplikasi industri. Brevibacillus themoruber LII diperoleh dari penelitian sebelumnya pada penapisan isolat potensial penghasil protease tahan panas dari sumber air panas Indonesia. Protease baru tahan panas yang dihasilkan oleh Brevibacillus thermoruber LII sudah dimurnikan dan dikarakterisasi. Diprediksi bahwa enzim murni yang dihasilkan oleh mikroorganisma tahan panas, Brevibacillus thermoruber LII merupakan heksamer dengan berat molekul unit yang sama yaitu $36 \mathrm{kDa}$ dan nativenya $215 \mathrm{kDa}$.Lebih lanjut, protease ini merupakan protease metaloserin netral berdasarkan uji-uji biokimianya yang dihambat sepenuhnya oleh PMSF (Phenylmethanesulfonyl fluoride) and EDTA (Ethylenediaminetetraacetic acid). Enzim menunjukkan aktifitas optimum pada $\mathrm{pH} 8$ dan aktif lebih baik pada $\mathrm{pH}$ bufer bersifat asam (sampai $\mathrm{pH}$ 4). Semua ion logam (2.5 $\mathrm{mM}$ ) dalam bentuk garam-garam khlorida yang diujikan dapat meningkatkan aktivitas enzim kecuali $\mathrm{Li}^{2+}$ lon $\mathrm{Ca}^{2+}$ paling mempengaruhi aktivitas enzim (meningkatkan sampai 250\%) dan kestabilan terhadap panas. Protease LII mempunyai suhu optimum $60^{\circ} \mathrm{C}$ tanpa penambahan $\mathrm{CaCl}_{2}$ dan $80-85^{\circ} \mathrm{C}$ ketika ditambahkan $\mathrm{CaCl}_{2}$. Enzim juga menunjukkan kestabilan terhadap pelarut organik. Nilai $\mathrm{K}_{\mathrm{M}}$ dan $\mathrm{V}_{\max }$ enzim murni masing-masing adalah $27.2 \mathrm{mg} / \mathrm{ml}$ atau 0.362 $0.272 \mathrm{M}$ dengan substrat HammersteinCasein (MM 75-100 kDa) dan $261.1 \mathrm{\mu g} / \mathrm{menit} / \mathrm{ml}$.
\end{abstract}

Kata Kunci: protease tahan panas, Brevibacillus thermoruber, sumber air panas 


\section{Introduction}

Protease are one of the most important enzyme in industrial and academic fields. It approximately consist of $60 \%$ in enzyme market (Rao et al., 1998). The use of protease was predicted up to 250 billon US $\$$ by 2010 (Turk, 2006). They are largely applied in leather, detergent, brewing protein modification, meat, photographic, dairy, waste treatment, and membrane cleansing industries (Kumar, 2002; Chu, 2007). The demand of the enzyme are predicted to increase due to the need of the enzyme, which can resist on rough industrial process.

Thermostability is among of the vital enzyme characteristics for industrial application The benefits of using thermostable enzymes in industry include the capability to use elevated temperatures, thus increasing the solubility of non gaseous reactants/ products, allowing more rapid reactions, and decreasing the occurrence of microbial contamination by mesophilic organisms (Sookkheo et al., 2000; Chen et al., 2006). In a raised temperature range, a hardto-degrade protein tends to achieve plasticity results in more susceptibleness to enzymatic degradation (Suzuki et al., 2006). Moreover, the use of thermophiles and their derived enzymes is effective for the breaking of hard-to-degrade proteins such as collagen (Okamoto et al., 2001; Watanabe, 2004), keratin (Nam et al., 2012), and prion protein (Tsiroulnikov et al., 2004).

Brevibacillus thermoruber was reported at first as a new species of Bacillus by Manachini et al. (1988). This species showed protease producing capacity at optimum temperature of $45^{\circ} \mathrm{C}$ and optimum $\mathrm{pH} 9$. Wang et al. (2012) reported a Brevibacillus species that produced thermostable protease with slightly different characters to the one which was produced by strain LII (optimum temperature $75^{\circ} \mathrm{C}$ and optimum $\mathrm{pH}$ 9) . Another experiment on these bacteria was reported by Lee et al. (2004). Lee's group reported the presence of a gene encoding Lon Protease in Brevibacillus thermoruberWR-249. Lon proteases are ATP-dependent serine peptidases belonging to the MEROPS peptidase family S16 (Lon protease family, clan SF). Brevibacillus thermoruber had also been reported for its ability to degrade fibroin which is one of the substrates of protease (Suzuki et al., 2009).

Brevibacillus thermoruber LII was obtained as a potential isolate from the previous research which screened the potential thermostable protease producing bacteria from Padang Cermin, an Indonesian hot spring. The intensive screening at elevated temperature not only conducted on solid medium but also whitin liquid medium. The crude enzyme showed the highest activity at $85^{\circ} \mathrm{C}$, stable for up to 100 minutes at $75^{\circ} \mathrm{C}$ with optimum pH of $8-9$ (Zilda et al., 2012a). The investigation on optimization of enzyme production showed that LII protease was produced optimally at $50-55^{\circ} \mathrm{C}, \mathrm{pH} 5-7$. The addition of feather keratin in production medium resulted the enzyme with remarkable activity compared to those supplemented with casein, skim milk and collagen. The capability of this isolated on degradation of whole feather keratin also has been investigated (Zilda et al., 2012b). All reports showed that thermostable protease produced by LII had the different characteristics from any thermostable protease produced by the same genus regarding to the optimum temperature and stability against thermal that have been done on crude enzyme.

\section{Material and Methods}

\subsection{Material}

Brevibacillus thermoruber LII was isolated from Padang Cermin Hotspring, Indonesia. Feather keratin was prepared by washing chicken feathers with tap water followed by sun drying. Subsequently, the dried feathers were boiled in $0.0125 \mathrm{M} \mathrm{NaOH}$ for 20 minutes, neutralized with $\mathrm{HCl}$, and then again sun dried. The above procedure was repeated twice before the samples were ground and used as the substrate (Rahayu, 2010).

The medium for protease production was contained of $0.1 \% \mathrm{NaCl}, 0.1 \% \mathrm{~K}_{2} \mathrm{HPO}_{4}, 0.01 \% \mathrm{MgSO}_{4} 7 \mathrm{H}_{2} \mathrm{O}$, $0.05 \%$ yeast extract and $0.5 \%$ feather keratin. The culture was incubated at $50^{\circ} \mathrm{C}$ for 22 hours as previous reported as optimum condition for protease production (Zilda et al., 2012b). After incubated in respective medium for required time, the culture of Brevibacillus thermoruber LII was filtered through Whatman No. 1 filter paper to separate remained feather keratin and then centrifuged at $10,000 \mathrm{rpm}$ for $10 \mathrm{~min}$. The clear cell free culture supernatant was used as enzyme source for further studies.

\subsection{Methods}

\subsubsection{Protease Purification}

Two liters of crude protease harvested by centrifugation and the supernatant was concentrated and filtered by continuous ultrafiltration (Sartorius) equipped with a 5000 Da cut-off membrane (Amersham). The sample was loaded onto a column of DEAE Sepharose Fast Flow $(1.6 \times 10 \mathrm{~cm}$, Amersham) pre-equilibrated with $25 \mathrm{mM}$ Tris- $\mathrm{HCl}$ buffer , pH 9.0 (buffer A). Bounded proteins were eluted at a flow rate of $1 \mathrm{ml} / \mathrm{min}$ by applying a linear $\mathrm{NaCl}$ gradient $(0-1.5 \mathrm{M})$ in buffer $A$ and fractions were collected at 5 
$\mathrm{ml}$. The active fractions were pooled and applied to Sepacryl S200 $1 \mathrm{~cm}$ x $60 \mathrm{~cm}$, (Amersham), equilibrated in $25 \mathrm{mM}$ Tris- $\mathrm{HCl}$ buffer, $\mathrm{pH}$ 9.0. The elution was performed with the same buffer, at a flow rate of $0.5 \mathrm{ml} / \mathrm{min}$ and fractions of $3 \mathrm{ml}$ were collected. The fractions with proteolytic activity were pooled and used for further characterization.

\subsubsection{Molecular Weight Determination}

SDS PAGE method in $10 \%$ polyacrylamide slab gel described by Laemmli (1970) carried out to analyze the molecular mass. For zymogram analysis, protease was separated in a $10 \%$ SDS-polyacrylamide gel containing $0.5 \%$ gelatin as substrate. The samples were not heated prior to electrophoresis at a constant current of $8 \mathrm{~mA} / \mathrm{gel}$. The gel was washed with $2.5 \%$ Triton X-100 for 1 hour and incubated for 30 minute in $25 \mathrm{mM}$ Tris- $\mathrm{HCl}$ buffer, $\mathrm{pH} 9.0$ at $75^{\circ} \mathrm{C}$. The gel was stained with Coomassie brilliant blue R-250 $(0.1 \% \mathrm{w} /$ v) for $30 \mathrm{~min}$ and then destained in distilled water/ methanol/acetic acid (50:40:10). The protease band appeared as clear zone surrounded by dark blue color of the gel.

\section{Characterization of Protease}

\subsection{Determination of Active Site by Amino Acid Blocking}

Modification of the histidine, cysteine, and serine residue was performed by pre-incubating the protease with 4-bromophenacyl bromide, iodoacetamide (IAA), and phenyl methylsulphonyl fluoride (PMSF), respectively, at a final inhibitor concentration of $1 \mathrm{mM}$ at room temperature $\left(25^{\circ} \mathrm{C}\right)$ for $30 \mathrm{~min}$ and then assaying the protease activity against appropriate control (Rai \& Mukherjee, 2009). The inhibition effect was also investigated by zymogram analysis.

\subsection{Effect of Metal lons on Protease Activity}

Effect of various metal ions on enzyme activity was determined by incubating the enzyme with 2.5 $\mathrm{mM}$ metal ions $\mathrm{C} \mathrm{O}^{2+}, \mathrm{Mg}^{2+}, \mathrm{Li}^{2+}, \mathrm{Fe}^{2+}, \mathrm{Cu}^{2+}, \mathrm{Zn}^{2+}$; $\mathrm{Mn}^{2+}$, and $\mathrm{Ca}^{2+}$ ) at $45^{\circ} \mathrm{C}$ for 30 minutes. The enzyme activity without metal ion served as the control and was considered as $100 \%$ activity.

\subsection{Effect of Temperature on Protease Activity and Its Stability}

To determinate the optimum temperature of enzyme, $250 \mu$ l of enzyme was mixed with $250 \mu \mathrm{L}$ of 1 $\%$ casein and incubated at different temperatures (50$90^{\circ} \mathrm{C}$ ). After 10 minutes the reaction was terminated by adding $500 \mu \mathrm{L}$ of $0.4 \mathrm{M}$ TCA. Then the protease activity was measured as described earlier. The stability of enzyme was measured by incubating the enzyme at different temperatures $(50,55$ and 60 without $\mathrm{CaCl}_{2} ; 60,65$ and $70^{\circ} \mathrm{C}$ with $2.5 \mathrm{mM} \mathrm{CaCl}_{2}$ ) up to 3 hours and assayed for its activity. The enzyme without heat treatment was considered as $100 \%$ activity.

\subsection{Determination of Optimum $\mathrm{pH}$ and Its Stability}

The effect of $\mathrm{pH}$ on protease activity and its stability was determined by incubating the enzyme with different $\mathrm{pH}(4-10)$ buffer for 2 hours. The enzyme was then loaded on to polyacrylamid-substrate gel and incubated at the same $\mathrm{pH}$ buffer. The optimum $\mathrm{pH}$ and its stability will determined by the clearest zone appeared on the gel after staining with coomassine blue.

\subsection{Effect of Solvents on Protease Activity}

Investigation on effect of solvents ( ethanol, methanol, acetone, acetonitrile, ethyl acetate and diethyl ether) on protease activity was determined by incubating enzyme with $5 \%$ of solvents at $45^{\circ} \mathrm{C}$ for 30 minutes and assayed for its activity. The enzyme activity without solvents served as the control which was considered as $100 \%$ activity.

\subsection{Effect of Detergent and Chemical On Pro tease Activity}

Investigation on effect of different concentration of surfactant (SDS, Tween-80, Triton X-100), metal ion chelator (ethylenediaminetetraacetic acid (EDTA), and dithiothreitol (DTT) was determined by incubating enzyme with $1 \%$ of detergent (1\%) and metal $1 \mathrm{mM}$ of EDTA and DTT at $45^{\circ} \mathrm{C}$ for 30 minutes and assayed for enzyme activity. The enzyme activity without chemicals served as the control which was considered as $100 \%$ activity

\subsection{Determination of Kinetic Parameters}

The reaction rate of the purified protease was determined at various concentrations of casein (1 to $15 \mathrm{mg} / \mathrm{ml}$ ) prepared in $25 \mathrm{mM}$ Tris- $\mathrm{HCl}$ buffer. The kinetic parameters were measured using the equation:

$$
1 / \mathrm{V}=1 / \mathrm{V}_{\max }+\mathrm{K}_{\mathrm{M}} \mathrm{N}_{\max } 1 /[\mathrm{S}]
$$

The plot of $1 / \mathrm{V}$ versus $1 /[\mathrm{S}]$ would result a straight line with a $y$-intercept $=1 / \mathrm{V}_{\max }$ and a slope $=\mathrm{K}_{\mathrm{M}} / \mathrm{V}_{\max }$ which is called a Lineweaver-Burke plot (Voet and Voet, 2004). 


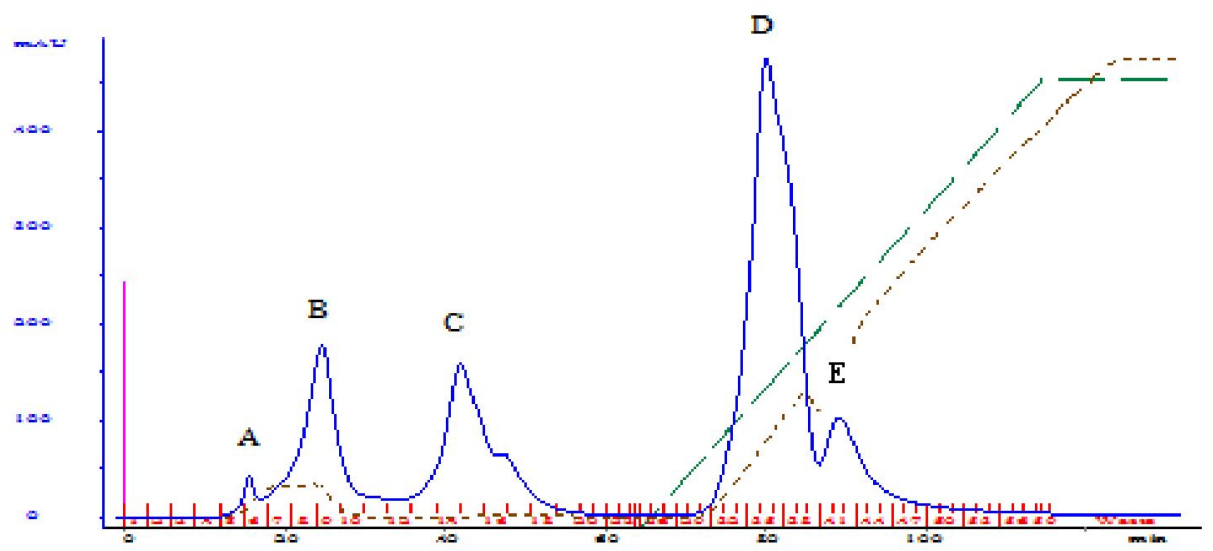

Figure 1. DEAE sepharose profile of concentrated protease LII copied from unicorn software connected to FPLC. The fractionation was carried out with $\mathrm{NaCL}(0-1,5 \mathrm{M})$ in $25 \mathrm{mM}$ Tris-Cl buffer $\mathrm{pH}$ of 9 , flow rate $1 \mathrm{ml} /$ minute with $5 \mathrm{ml}$ of fraction collection. Arrow indicates the fraction with highest protease activity. Protease activity was measured with $1 \%$ casein in $2.5 \mathrm{mM}$ Tris- $\mathrm{Cl}$ buffer $\mathrm{pH}$ of 9 at temperature of $85^{\circ} \mathrm{C}$.

\section{Result and Discussion}

\subsection{Protease Purification}

Brevibacillusthemoruber LII was isolated from Indonesian hotspring along with 2 other strain which produced a potential thermostable protease. Previous work showed that crude thermostable protease produced by Brevibacillus thermoruber LII optimally active at $85^{\circ} \mathrm{C}, \mathrm{pH} 9$, and stable at temperature $70^{\circ} \mathrm{C}$ up to 100 minutes (Zilda, 2012a). This characteristics were used as condition for measuring the enzyme activity in this paper.

The fractionation of concentrated enzyme on DEAE sepharose separated the sample into five protease peaks, designated as A-E (Figure 1). Peak B showed the highest activity at $85^{\circ} \mathrm{C}$. The peak $A$ showed the protease activity after applied on to sepacryl S200 (Figure 2). The purification summary of this enzyme is displayed in Table 1.

\subsection{Molecular Weight Determination}

The observed single band in SDS-PAGE suggested that the purified protease from Brevibacillus thermoruber LII was homomer with molecular weight of $36 \mathrm{kDa}$ (Figure 3A). Zymogram activity staining revealed one zone of gelatin hydrolysis for the purified sample co-migrating with molecular weight of $215 \mathrm{kDa}$ (Figure 3B). LIl protease was confirmed as homomer since the denaturized enzyme showed the single band so that the molecule was predicted consisting about

is

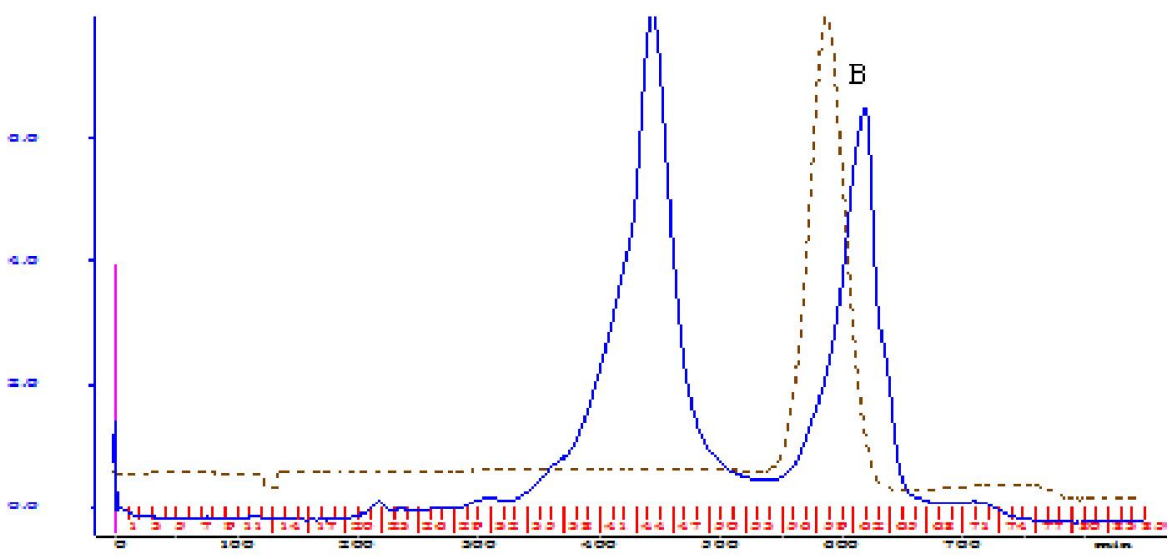

Figure 2. Sepacryl S200 profile of Peak A from DEAE fractionation copied from unicorn software connected to FPLC. The fractionation was carried out using $120 \mathrm{ml}$ matrix equilibrated with $2.5 \mathrm{mM} \mathrm{Tris-Cl}$ buffer, flow rate $0.5 \mathrm{ml} /$ minute and $3 \mathrm{ml}$ fraction collection. Arrow indicates the fraction with protease activity. Protease activity was measured with $1 \%$ casein in $2.5 \mathrm{mM}$ Tris-Cl buffer $\mathrm{pH}$ of 9 at temperature of $85^{\circ} \mathrm{C}$. 
Table 1. Purification summary of thermostable protease produced by Brevibacillus thermoruber LII

\begin{tabular}{lcrrrr}
\hline Step & $\begin{array}{c}\text { Total activity Total protein } \\
(\mathrm{U} / \mathrm{ml})\end{array}$ & \multicolumn{1}{c}{$\begin{array}{c}\text { Specific } \\
(\mathbf{m g})\end{array}$} & $\begin{array}{r}\text { activity }(\mathrm{U} / \mathrm{mg}) \\
\text { Purification } \\
\text { fold }\end{array}$ & \multicolumn{1}{c}{$\begin{array}{c}\text { Yield } \\
(\%)\end{array}$} \\
\hline Crude & 88242,11 & 210,50 & 419,21 & 1 & 100 \\
DEAE & 23648,42 & 6,53 & 3618,98 & 8,63 & 26,79 \\
sepacryl & 2817,68 & 0,60 & 4696,98 & 11,20 & 3,19 \\
\hline
\end{tabular}
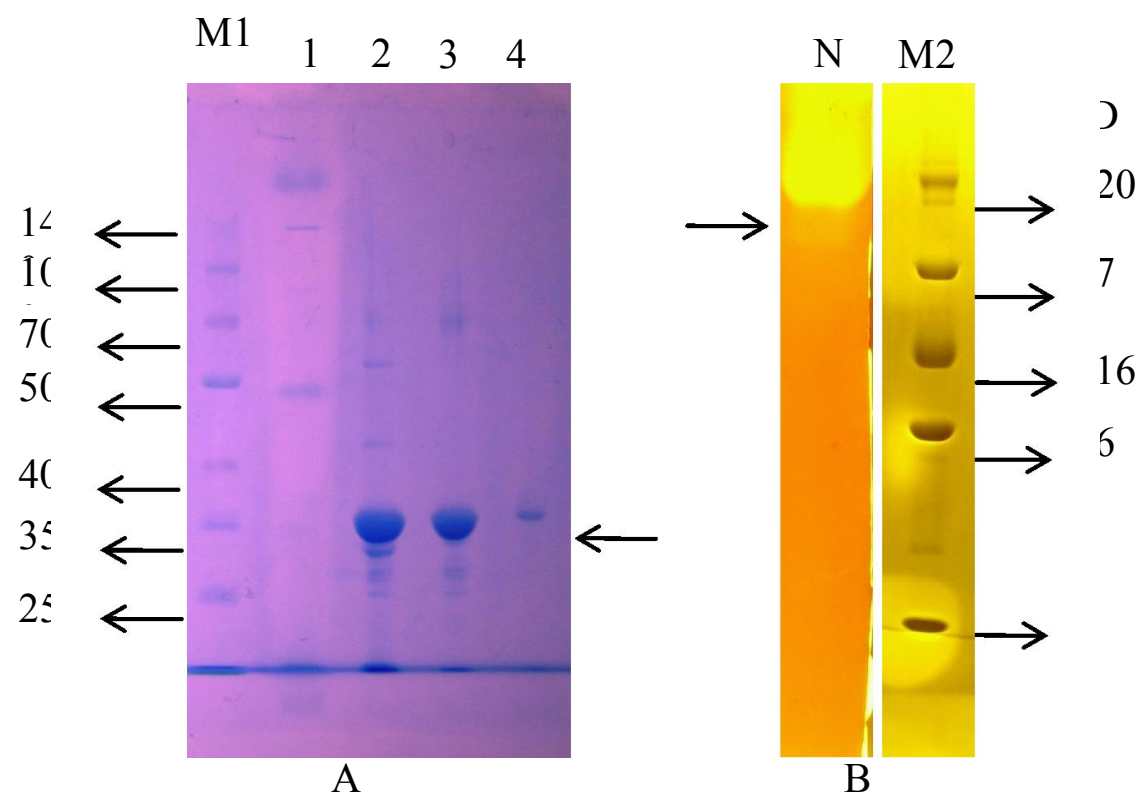

Figure 3. SDS-PAGE in $12 \%(\mathrm{w} / \mathrm{v})$ polyacrylamide slab gel of thermostable protease LII purification (A) Lane M1: Spectra Multicolor Broad Range Protein Ladder (Thermo Scientific), lane 1: Crude enzyme, Lane 2: Ultra filtration, Lane 3: DEAE fraction, Lane 4: Sepacryl S200 fraction. (B) Lane N:LII (native), M2: Native Molecular Weight Marker (Amersham).

six subunits or hexameric. The observation to determine the native molecular weight of protease using zymogram analysis also described by Bhargavi \& Prakasham, (2013) and Jaouadi et al., (2010) who determine the molecular weight of protease produced by Seratia sp. RSPB 11 and Streptomyces sp. strain $A B 1$ respectively.

Zymography is an electrophoresis technique, based on sodium dodecyl sulphate polyacrylamide gel electrophoresis (SDS-PAGE) and a substrate copolymerized with the polyacrylamide matrix. Proteins are prepared by the standard SDS-PAGE buffer under non-reducing conditions (no boiling and no reducing agent), and are separated by molecular weight in the standard denaturing SDSPAGE. The active enzymes will hydrolyze the embedded substrate, and then proteolytic activity can be visualized as cleared bands on a coomassie stained background (Heussen \& Dowdle, 1980).
Some of serine proteases were reported as monomeric protease (Zhu et al., 2007; Rachadech et al., 2010; Mazar et al., 2012). Bacillus sp. strain MO1 produced protease consisted of two large sub units (105 kDa) or dimeric (Okamoto et al., 2001). Dimeric protease also produced by Aeromonas veronii PG01 with molecular weight of $33 \mathrm{kDa}$ as denaturized protein and $66 \mathrm{kDa}$ as non-denaturized one (Divakar et al., 2010). There were no reports found about hexameric protease as be produced by Brevibacillus thermoruber LII.

Varieties of molecular weight for denaturized proteases from other Bacillus species had been reported: $30.9 \mathrm{kDa}$ from thermophilic Bacillus strain HS08 (Huang et al., 2006); $27.0 \mathrm{kDa}$ from Bacillus megaterium (Reungsang et al., 2006); $75.0 \mathrm{kDa}$ from Bacillus sp. S17110 (Jung et al., 2007); $34.0 \mathrm{kDa}$ from Bacillus thuringiemis (Kunitate et al., 1989); $38.0 \mathrm{kDa}$ from Bacillus cereus KCTC 3674 (Kim et al., 2001); 
$15.0 \mathrm{kDa}$ from Bacillus subtilis PE-11 (Adinarayana et al., 2003) and $34.0 \mathrm{kDa}$ from Bacillus cereus BG1 (Ghorbel-Frikha et al., 2005).

\subsection{Determination of Active Site by Amino Acid Blocking}

The active site of protease can be determined by modification of the histidine, cysteine, and serine residue which was performed by pre-incubating the protease with 4-bromophenacyl bromide (BPB), iodoacetamide (IAA) and phenyl methylsulphonyl fluoride (PMSF). After incubation LII protease with PMSF for 30 minutes at $45^{\circ} \mathrm{C}$, the zymogram analysis showed no clear zone (Figure 4). The measurement of enzyme activity after incubation showed that PMSF completely inhibited enzyme activity and there was no effect on the enzyme activity with addition of BPB but with IAA the activity was retained $91 \%$ (Table 2 ) . Based on the results, the LII protease could be classified as a serine protease.

\section{Biochemical Characterization}

\subsection{Effect of Metal lons on Protease Activity}

Metal ions such as $\mathrm{Mn}^{2+}, \mathrm{Zn}^{2+}, \mathrm{Ca}^{2+}$ and $\mathrm{Mg}^{2+}$ had a stimulatory effect on protease activity. This effect was also reported to increase the thermostability of other Bacillus proteases (Paliwal et al.,1994; Rahman et al., 1994). The remarkable activity was observed after the incubation of LII protease with metal ions $(2.5 \mathrm{mM})$. This experiment showed that the protease activity increased more than $200 \%$ in the presence of $\mathrm{Mg}^{2+}, \mathrm{Mn}^{2+}, \mathrm{Ca}^{2+}$ and $\mathrm{Cu}^{2+}$. There was no metal ion used in this research inhibiting the activity of the protease (Figure 5). Some thermostable serine proteases were inhibited by ion $\mathrm{Zn}^{2+}, \mathrm{Mn}^{2+}, \mathrm{Cu}^{2+}, \mathrm{Co}^{2+}$ and $\mathrm{Fe}^{2+}$ such as protease produced by Pseudomonas strain which was inhibited by ion $\mathrm{Zn}^{2+}$ and $\mathrm{Mn}^{2+}$ (Patil \& Chaudhari 2009; Gupta et al., 2005) and thermostable serine protease produced Bacillus pumilus which was inhibited by $\mathrm{Zn}^{2+}$ and $\mathrm{Fe}^{2+}$ (Jayakumar et al., 2012). Thermostable serine protease generated by Bacillus sp. strain MO-1 was completely inhibited by $\mathrm{Fe}^{2+}$ (Okamoto et al., 2001). Brevibacillus sp. strain PLI-1 produced thermostable protease which was completely inhibited by $\mathrm{Zn}^{2+}$ and $\mathrm{Fe}^{3+}$ (Wang et al., 2012).

\subsection{Effect of Temperature and Its Stability}

Since thermostable protease produced by Brevibacillus thermoruber LII was serine metaloprotease, which was stimulated by $\mathrm{Ca}^{2+}$ ion, the effect of temperature on enzyme activity and its stability was investigated through the addition of 2.5 $\mathrm{mM}$ of $\mathrm{CaCl}_{2}$ at temperature of $55-95^{\circ} \mathrm{C}$ as shown in Figure 6.

The result showed that optimum temperature of purified protease produced by Brevibacillus thermoruber LII was $60^{\circ} \mathrm{C}$ without addition of $\mathrm{CaCl}_{2}$ and $80-85^{\circ} \mathrm{C}$ with addition of $2.5 \mathrm{mM}$ of $\mathrm{CaCl}_{2}$. The activity of the enzyme with the presence of $\mathrm{CaCl}_{2}$ was seen to be lower at temperature $55-60^{\circ} \mathrm{C}$ compared to enzyme activity without $\mathrm{CaCl}_{2}$ (Figure 6). The

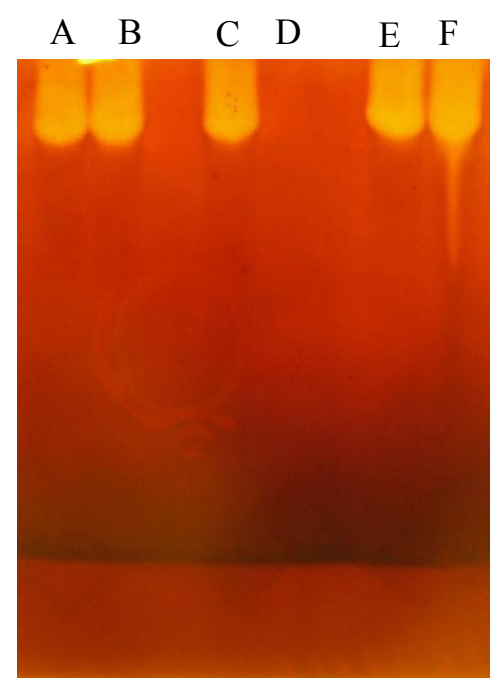

Figure: 4. Zymogram analysis of amino acid blocking. The purified protease LII was loaded after 30 minutes incubation at $45^{\circ} \mathrm{C}$ with chemical blocker. The experiment was carried out using $12 \%$ polyacrylamyde and incubated at $75^{\circ} \mathrm{C}$ with Tris-Cl buffer $\mathrm{pH}$ of 9 for 30 minutes. (Lane A: Control IAA, B. Enzyme with IAA, C. Control PMSF, D. Enzyme with PMSF, E. Control DBP andF. Enzyme with BPB). 
Table 2. Effect of various inhibitors and chemicals on the activity of thermostable protease produced by Brevibacillus thermoruber LII

\begin{tabular}{lr}
\hline Characteristics & \\
\hline Inhibitors/Chemicals & Relative Activity (\%) \\
\hline PMSF & 0 \\
IAA & 92,75 \\
BPB & 99,22 \\
EDTA (1mM) & 0 \\
DTT (1mM) & 0 \\
Tween $80(1 \%)$ & 98,25 \\
SDS (1\%) & 22 \\
Triton x100 (1\%) & 97.68 \\
Metal ions $^{2+}$ & \\
$\mathrm{Li}^{2+}$ & 99,88 \\
$\mathrm{Mg}^{2+}$ & 203,39 \\
$\mathrm{Mn}^{2+}$ & 206,15 \\
$\mathrm{Ca}^{2+}$ & 258,57 \\
$\mathrm{Zn}^{2+}$ & 166,18 \\
$\mathrm{Cu}^{2+}$ & 235,71 \\
$\mathrm{Fe}^{3+}$ & 126,69 \\
$\mathrm{Co}^{2+}$ & 199,21 \\
Organic solvents $_{\text {Ethanol }}$ & \\
$\mathrm{Methanol}^{2+}$ & 100 \\
$\mathrm{Acetone}^{2+}$ & 93,5301 \\
$\mathrm{Acetonitrile}_{\text {Ethyl acetate }}$ & 100 \\
$\mathrm{Diethyl} \mathrm{ether}^{2}$ & 69,69 \\
\hline & 97,15 \\
& 97,6 \\
\hline
\end{tabular}

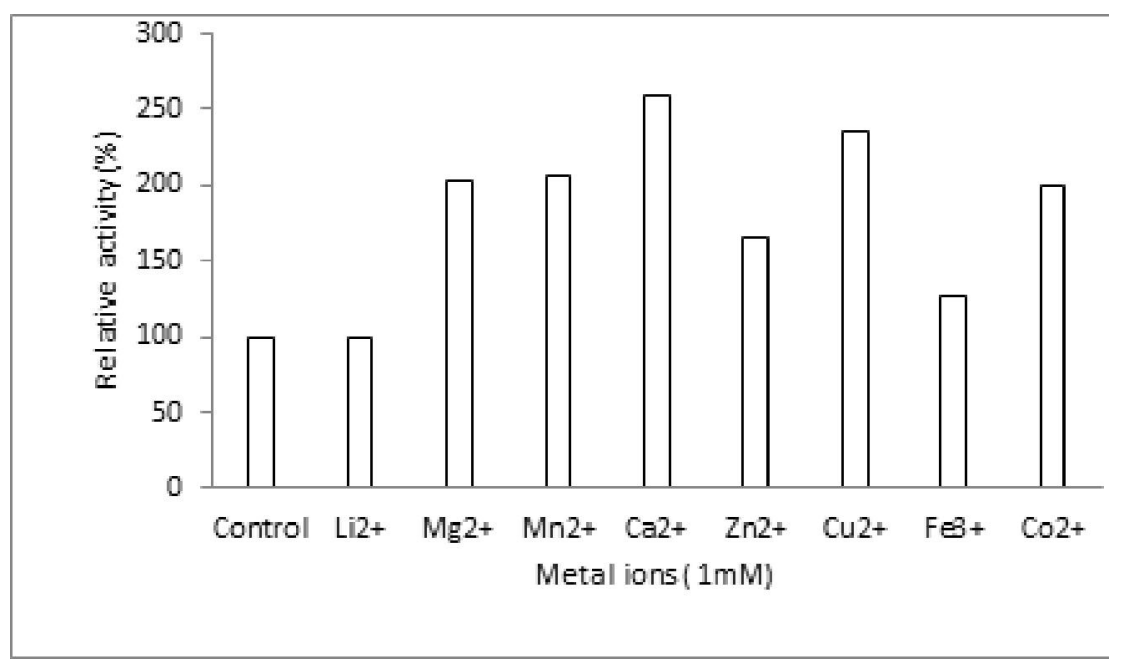

Figure 5. The activity of purified protease LII after incubation with various of $2.5 \mathrm{mM}$ metal ions at $45^{\circ} \mathrm{C}$ for 30 minutes. The activity was measured with $1 \%$ casein in $2.5 \mathrm{mM}$ Tris- $\mathrm{Cl} \mathrm{pH}$ of 8 and temperature of $85^{\circ} \mathrm{C}$. 


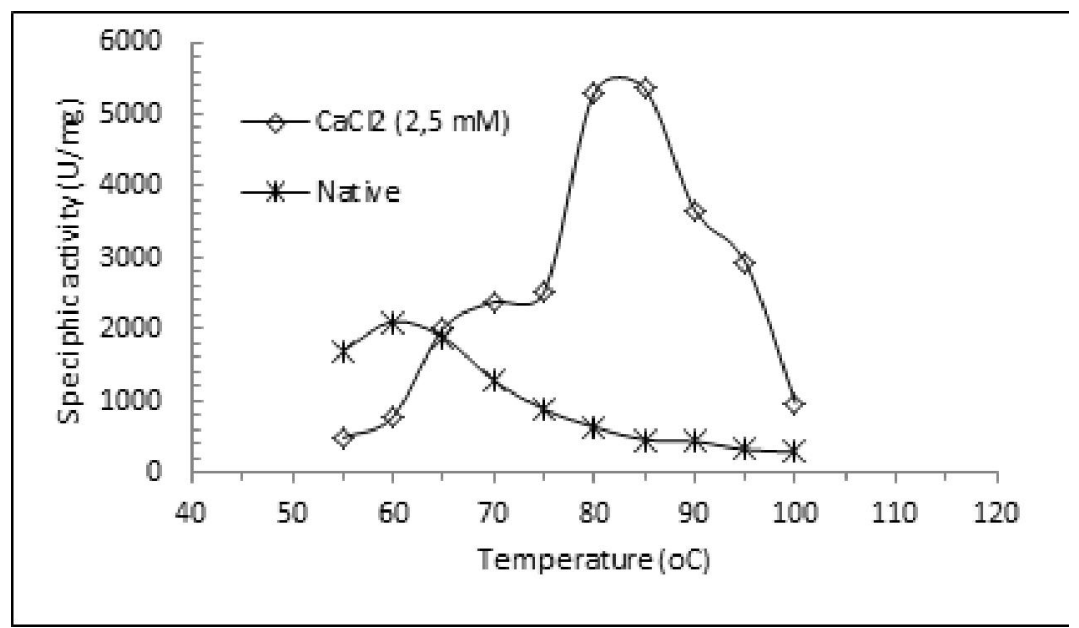

Figure 6. Activity of purified protease LII (native and with $2.5 \mathrm{mM} \mathrm{CaCl}_{2}$ ) at different of temperature (55$100^{\circ} \mathrm{C}$ ). The activity was measured with $1 \%$ casein in $25 \mathrm{mM}$ Tris-Cl buffer $\mathrm{pH}$ of 8 .

enzyme with $\mathrm{CaCl}_{2}$ showed maximum stability at temperature of $65^{\circ} \mathrm{C}$ (not presented). The thermostability of thermostable protease is mostly influenced by $\mathrm{Ca}^{2+}$ ion as reported by Asoodeh and Musaabadi, (2012), Jayakumar et al. (2012), Ghorbel et al. (2003) and Johnvesly \& Naik, (2001). Two extracellular enzymes produced by thermophilic microorganisms required $\mathrm{Ca}^{2+}$ ion for their stabilities (Peek et al., 1992; Arulmani et al., 2007).

\subsection{Effect of $\mathrm{pH}$ and It's Stability}

The previous result showed that LII preferred acidic to basic medium to produce the protease (Zilda et al., $2012^{a}$ ). The zymogram analysis which was conducted by incubating the acrylamid-substrate gel in various of $\mathrm{pH}$ ( 4-10) buffer showed that the enzyme was active in all of $\mathrm{pH}$ range with optimum $\mathrm{pH}$ of 8 (data not shown).

The same characteristic showed by Brevibacillus sp. PLI-1 thermostable protease (Wang et al., 2012). The protease produced by Bacillus thermantarcticus, strain $\mathrm{M} 1$ was active over $\mathrm{pH}$ range 4.0-10.0 with an optimum of pH 7.0 (Dipasquele et al., 2008). Pseudomonassp. DR89 produced neutral protease which was active in range $\mathrm{pH}$ from 5 to 11 with an optimum pH of 8.0 (Assodeh \& Musaabadi, 2012).

\subsection{Effect of Solvent on Protease Activity}

It was reported that the proteases are unstable in organic solvents (Jayakumar et al.,2012). Hence, the need for organic solvent stable and thermostable protease is of much concerned as it could withstand at harsh industrial process conditions. Purified enzyme of Bervibacillus thermoruber LII inhibited about $2.4,2.9$ and 6.5 and $30,3 \%$, by diethyl ether, ethyl acetate, methanol and acetonitrile repectively after preincubated for 30 minutes. No inhibition detected with addition of ethanol and acetone (Table 2).

\subsection{Effect of Chemicals and Detergent on Protease Activity}

Thermostable protease produced by Brevibacillus thermoruber LII completely was inhibited by EDTA and DTT. SDS also found inhibited this enzyme. Enzyme activity was not influenced by Incubation of the enzyme with $1 \%$ of Triton-X 100 and Tween 80 . The inhibition produced by DTT might be due to reduction of intramolecular disulphide bonds required to maintain the activity and stability of the enzyme (Rai et al., 2010).

The summary of biochemical characteristics of thermostable protease produced by Brevibacilus thermoruber LII is presented in Table 2.

\subsection{Determination of Kinetic Parameters}

The kinetic parameters, including $\mathrm{Km}$ and $\mathrm{Vmax}$ values towards casein as a substrate, were determined. The $\mathrm{K}_{\mathrm{M}}$ and $\mathrm{V}_{\max }$ values for purified protease LII were $27.2 \mathrm{mg} / \mathrm{ml}$ or $0.362-0.272 \mathrm{M}$ for its substrate HammersteinCasein (MM 75-100 kDa) and $261.1 \mu \mathrm{g} / \mathrm{minute} / \mathrm{ml}$ respectively (Figure 7).

Thermostable protease produced by Pseudomonas sp. DR89 (Assodeh \& Musaabadi, 2012), Bacillus thermantarcticus M1 (Dipasquale et al., 2008), Paenibacillus tezpurensis sp. nov. AS-S24-II (Rai et al., 2010) have $\mathrm{Km}$ value of $0.76,1$ and $0,2 \mathrm{mg} / \mathrm{ml}$ 


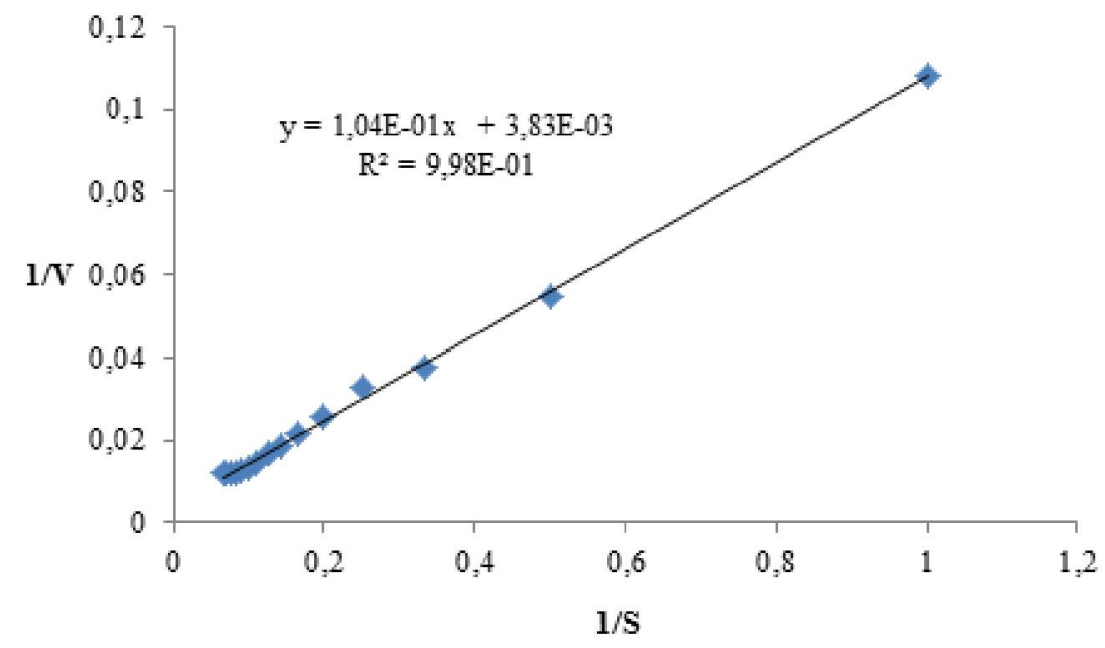

Figure 7. Lineweaver-Burk curve of the purified protease LII activity.

respectively which are lower than that produced by LII.

Dramatic loss of enzymatic activity, after observation of purified protease post-modification of serine residues by PMSF, suggested the involvement of this amino acid in the catalytic activity of the enzyme. Bacteria of the Bacillus genus secrete mostly two types of extracellular proteases, a neutral or metallo protease, and an alkaline protease which is functionally a serine endopeptidase, referred to as subtilisin. The first exhibited optimal $\mathrm{pH}$ at 7.0, whereas the latter had optimum $\mathrm{pH}$ between 9 and 11 (Ghorbel et al., 2003). LII protease belongs to the first group since the optimum $\mathrm{pH}$ was 8.0 and active more at acid $\mathrm{pH}$ than basic one. Subsequently, the addition of EDTA (1 $\mathrm{mM})$, a potent inhibitor of metalloprotease, totally inhibited enzyme activity as a result of metal ion chelation. These biochmical characterization and inhibition pattern provides a clear results that the protease produced by LII was neutral metalo serine protease.

The unique about this enzyme was all of metal ions tested had no inhibition effect and increased the enzyme activity. The increasing of protease activity indicated that there were protection of the protease activity by metal ions against thermal denaturation there by playing a vital role in maintaining the active confirmation of the protease at higher temperatures (Kumar \& Takagi, 1999). The kinetics parameter showed that LII protease has high $\mathrm{K}_{\mathrm{M}}$ value. It may means that LII protease have capability to work efficiently at a broad range of substrate.

\section{Conclusion}

LIl protease may be a good choice for application in food industries and peptide synthesis.
Nevertheless, intensive investigations were needed more since this result obtained from native enzyme. The activator such as $\mathrm{Ca}^{2+}$ and other metal ions can be used to improve its stability against organic solvent and other environment parameters.

\section{References}

Arulmani, M., Aparanjini, K., Vasanthi, K., Arumugam, P., Arivuchelvi, M., \& Kalaichelvan, P. T. (2007). Purification and partial characterization of serine protease from thermostable alkalophilic Bacillus laterosporus-AK1. World Journal of Microbiology and Biotechnology, 23(4), 475-481.

Asoodeh, A., \& Musaabadi, H. M. (2012). Purification and characterization of a thermostable neu-trophilic metalloprotease from Pseudomonas sp. DR89. Iranian Journal of Biotechnology, 10(2), 120-128.

Chen, T. L., Chou, Y. J., Chen, W. M., Arun, B., \& Young, C. C. (2006). Tepidimonas taiwanensis sp. nov., a novel alkaline-protease-producing bacterium isolated from a hot spring. Extremophiles, 10(1), 35-40.

Chu, W. H. (2007). Optimization of extracellular alkaline protease production from species of Bacillus. Journal of Industrial Microbiology \& Biotechnology, 34(3), 241-245.

Dipasquale, L., Calandrelli, V., Romano, I., Nicolaus, B., Gambacorta, A., \& Lama, L.,(2008). Purification and characterisation of a highly thermostable extracellular protease from Bacillus thermantarcticus, strain M1. Annals Microbiol, 58(2), 253-259.

Ghorbel, B., Sellami-Kamoun, A., \& Nasri, M. (2003). Stability studies of protease from Bacillus cereus BG1. Enzyme and Microbial Technology, 32(5), 513-518.

Gupta, A., Roy, I., Khare, S. K., \& Gupta, M. N. (2005). Purification and characterization of a solvent stable protease from Pseudomonas aeruginosa PseA. Journal of Chromatography A, 1069(2), 155-161.

Jayakumar, R., Jayashree, S., Annapurna, B., \& Seshadri, S. (2012). Characterization of thermostable serine alkaline protease from an alkaliphilic strain Bacillus 
pumilus MCAS8 and its applications. Applied biochemistry and biotechnology, 168(7), 1849-1866.

Kumar, C. G. (2002). Purification and characterization of a thermostable alkaline protease from alkalophilic Bacillus pumilus. Letters in Applied Microbiology, 34(1), 13-17.

Kumar, C. G., \& Takagi, H. (1999). Microbial alkaline proteases: from a bioindustrial viewpoint. Biotechnology Advances, 17(7), 561-594.

Lee Tsay, A. Y. L., Chen, M. Y., \& Wu, S. H. (2004). Identification of a gene encoding Lon protease from Brevibacillus thermoruber WR 249 and biochemical characterization of its thermostable recombinant enzyme. European Journal of Biochemistry, 271(4), 834-844.

Manachini, P. L., Fortina, M. G., \& Parini, C. (1988). Thermostable alkaline protease produced by Bacillus thermoruber a new species of Bacillus. Applied Microbiology and Biotechnology, 28 (4-5), 409-413.

Nam, G. W., Lee, D. W., Lee, H. S., Lee, N. J., Kim, B. C., Choe, E. A., Hwang, J. K., Suhartono, M. T., \& Pyun, Y. R. (2012). Native-feather degradation by Fervidobacterium islandicum AW-1, a newly isolated keratinase-producing thermophilic anaerob. Archaea Microbiology, 178, 538-547.

Okamoto, M., Yonejima, Y., Tsujimoto, Y., Suzuki, Y., \& Watanabe, K. (2001). A thermostable collagenolytic protease with a very large molecular mass produced by thermophilic Bacillus sp. strain MO-1. Applied Microbiology and Biotechnology, 57(1-2), 103-108.

Paliwal, N., Singh, S. P., \& Garg, S. K. (1994). Cationinduced thermal stability of an alkaline protease from a Bacillus sp. Bioresource Technology, 50(3), 209211.

Patil, U., \& Chaudhari, A. (2009). Purification and characterization of solvent tolerant, thermostable, alkaline metalloprotease from alkalophilic Pseudomonas aeruginosa MTCC 7926. Journal of Chemical Technology and Biotechnology, 84(9), 1255-1262.

Peek, K., Daniel, R. M., Monk, C., Parker, L., \& Coolbear, T. (1992). Purification and characterization of a thermostable proteinase isolated from Thermus $\mathrm{sp}$. strain Rt41A. European Journal of Biochemistry, 207(3), 1035-1044.

Rahayu, S. 2010. Study of Keratinase and Disulfide Reduktase Activity from Bacillus MTS on Keratin Degradation. Dissertation. Bogor Agricultural Institute. Bogor.

Rahman, R. N. Z. A., Razak, C. N., Ampon, K., Basri, M., Zin, W. M., Yunus, W., \& Salleh, A. B. (1994). Purification and characterization of a heat-stable alkaline protease from Bacillus stearothermophilus F1. Applied microbiology and biotechnology, 40(6), 822827.

Rai, S. K., \& Mukherjee, A. K. (2009). Ecological significance and some biotechnological application of an organic solvent stable alkaline serine protease from Bacillus subtilis strain DM-04. Bioresource Technology, 100(9), 2642-2645.

Rai, S. K., Roy, J. K., \& Mukherjee, A. K. (2010). Characterisation of a detergent-stable alkaline protease from a novel thermophilic strain Paenibacillus tezpurensis sp. nov. AS-S24-II. Applied Microbiology and Biotechnology, 85(5), 1437-1450.

Rao, M. B., Tanksale, A. M., Ghatge, M. S. and Deshpande, V. V. 1998. Molecular and biotechnological aspects of microbial proteases. Microbiology Molecular Biology Rev, 62, 597-635.

Sookkheo, B., Sinchaikul, S., Phutrakul, S., \& Chen, S. T. (2000). Purification and Characterization of the Highly Thermostable Proteases from Bacillus stearothermophilus TLS33. Protein Expression and Purification, 20(2), 142-151.

Suzuki, Y., Matsui, H., Tsujimoto, Y., \& Watanabe, K. (2009). Enzymatic degradation of fibroin fiber by a fibroinolytic enzyme of Brevibacillus thermoruber YAS1. Journal of Bioscience and Bioengineering, 108(3), 211-215.

Suzuki, Y., Tsujimoto, Y., Matsui, H., \& Watanabe, K. (2006). Decomposition of extremely hard-to-degrade animal proteins by thermophilic bacteria. Journal of Bioscience and Bioengineering, 102(2), 73-81.

Tsiroulnikov, K., Rezai, H., Bonch-Osmolovskaya, E., Nedkov, P., Gousterova, A., Cueff, V., ... \& Haertlé, T. (2004). Hydrolysis of the amyloid prion protein and nonpathogenic meat and bone meal by anaerobic thermophilic prokaryotes and Streptomyces subspecies. Journal of agricultural and food chemistry, 52(20), 6353-6360.

Turk, B. (2006). Targeting proteases: successes, failures and future prospects. Nature Reviews Drug Discovery, 5(9), 785-799.

Wang, S., Lin, X., Huang, X., Zheng, L., \& Zilda, D.S. (2012).Screening and characterization of the alkaline protease isolated from PLI-1, a strain of Brevibacillus sp. collected from Indonesia's hot springs. Journal. of Ocean. University of China, 11, 213-218.

Watanabe, K. (2004). Collagenolytic proteases from bacteria. Applied Microbiology and Biotechnology, 63(5), 520-526.

Zilda, D. S., Harmayani, E., Widada, J., Asmara, W., Irianto, H. E., Patantis, G., \& Fawzya, Y. N. (2012a). Screening of thermostable protease producing microorganisms isolated from Indonesian hotspring. Squalen, Bulletin of Marine and Fisheries Postharvest and Biotechnology. 7(3), 105 - 114.

Zilda, D.S., Harmayani, E., Widada, J., Asmara, W., Irianto, H.E., Patantis, G., \& Fawzya, Y.N.(2012b). Optimization of culture conditions to produce thermostable keratinolytic protease of Brevibacillus thermoruber LII, isolated from the Padang Cermin Hot Spring, Lampung, Indonesia, Microbiology Indonesia, 6(4), 194. 